\title{
Identification and Controlling of Stem Bulging of Passion Fruit (Passiflora Edulis) in Sri Lanka
}

\author{
R.G.A.S Rajapaksha ${ }^{1}$, I. Wahundeniya ${ }^{1}$, M.P.T. Premarathna ${ }^{1}$, Jeevani \\ Marasinghe $^{1}$, N. R. N. Silva ${ }^{1}$, E.R.S.P. Edirimanna ${ }^{2} \&$ Shyamalee $^{2}$

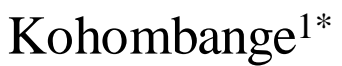

\footnotetext{
${ }^{1}$ Horticultural Crop Research and Development Institute, Gannoruwa, Sri Lanka .

${ }^{2}$ Fruit Crop Research and Development Institute, Horana.

*Corresponding Author
}

\begin{abstract}
Stem bulging is one of the major biological constrains of passion fruit cultivation especially in Low country wet zone areas in Sri Lanka. Green bark split as a result of bulging, discoloration ofbark and also stained internal tissues are the symptoms of this stem bulging. A survey was conducted in those infected areas to find out the causal factors of passion fruit stem bulging. Soil samples were collected from disease infected and disease free locations and analyzed for soil $\mathrm{pH}$, major nutrients and some micro nutrients. Examination of the internal tissues of stem showed at first inspection, looked like fungal hyphae. Microscopic observations were consistently indicated the Fusarium species association with infected tissues. Also, Passion fruit stem bulging samples were taken and dispatched to the CABI (Centre for Agriculture and Bioscience International) for further diagnosis of causal organism. The field trail - 1 was conducted at Agro ecological zone WLI a to observe the disease transmission of stem bulging from infected plants to healthy plants. The field trail - 2 was conducted at Agro ecological zone WL1a based on fungicides, insecticides and foliar fertilizer to control the stem bulging of passion fruit. The experiment was laid out in a Randomize Complete Block Design and five treatments were used with 3 replicates. The treatments were, T1Foliar application of insecticide - Thiamethoxam $25 \mathrm{WG}$ $3 \mathrm{~g} / 10 \mathrm{l}$, T2- Foliar application offungicide - Thiophanate methyl $70 \mathrm{WP} 6 \mathrm{~g} / 10 \mathrm{l}$, T3-Alternative foliar application of Thiamethoxam $35 \mathrm{WG}+$ Thiophanate methyl $70 \mathrm{WG}$, T4- Alternative foliar application of Thiamethoxam 25 $W G+$ Thiophanate methyl 70WP + Albert solution (commercial formulation of nutrient mixture) $5 \mathrm{~g} / 10 \mathrm{l}$ and T5-Control. Results numerated that, stem bulging can be transmitted from infected plant to healthy plants as a disease. Fusarium species were consistently found in bulged area of the samples tested. The lowest disease incidence was observed in Thiophanate methyl 70 WP treated plots of field trials indicating Fusarium species
\end{abstract}

may be the causal factor of the problem. Insecticide applications were failed in controlling stem bulging in the field conditions. According to the CABI report No: IMI 504215 \& IMI 504216, the isolation made from internal tissues and two fungal cultures were subjected for molecular identification and Gibberella fujikuroi and Fusarium sp. were identified as associate fungi of stem bulging of passion fruit.

Keywords - Stem bulging, Passion fruit, Gibberella fujikuroi, Fusarium sp.

\section{INTRODUCTION}

Stem bulging is one of the major biological constrains of passion fruit cultivation especially in Kalutara and Ratnapura districts (Agro ecological zone WL1a) in Sri Lanka since 1980s. Since then, this problem has gradually spread. Symptoms were observed in most of the farmer fields with different severity levels. The main symptoms observed in the affected vines were presented in Passion fruit stem branches. Green bark split as a result of bulging, discoloration of bark and also stained internal tissues. However initial examination showed no sign of fungal fruit bodies or insects.

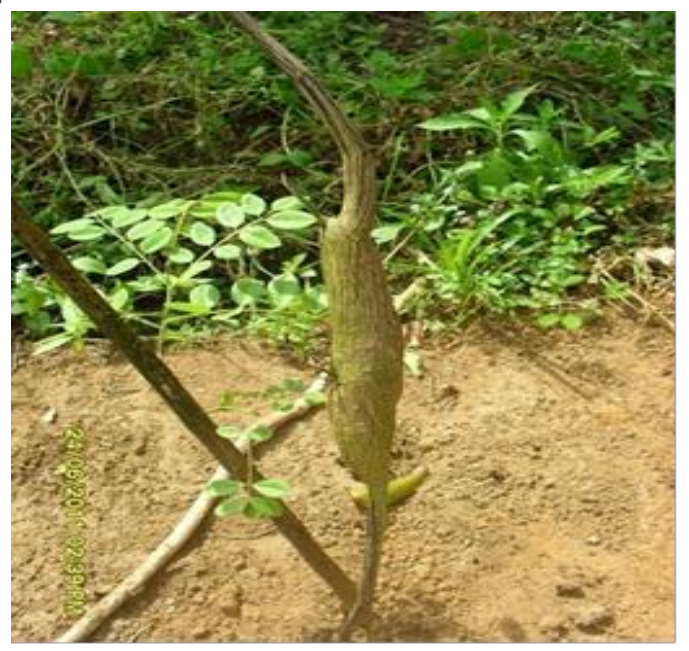

Fig.1: Passion fruit stem bulging 
Attempts have been made to develop some solutions for this problem. It was suspected that the symptoms resemble damaged caused by Boron deficiencies. However, application of Boron as a soil treatment ( $2 \mathrm{~g}$ of borax per vine) at planting failed to manage stem bulging problem of passion fruit. Preliminary field observations numerated that, stem bulging can be transmitted from diseased plant to healthy plants. So, we were identified stem bulging as a disease. Therefore, it was decided to carryout studies to correctly identify the causal factors and develop control measures for stem bulging of passion fruit in low country wet zone area.

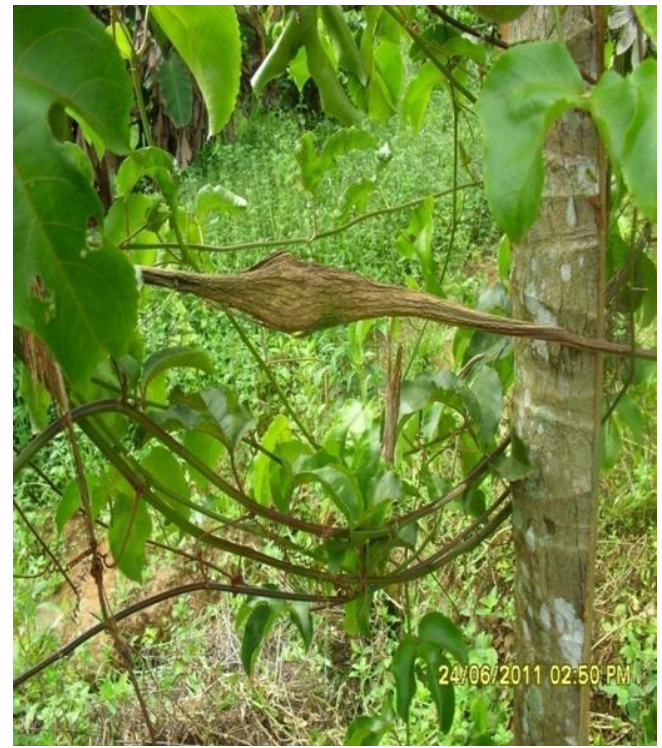

Fig.2: Green bark split as a result of bulging

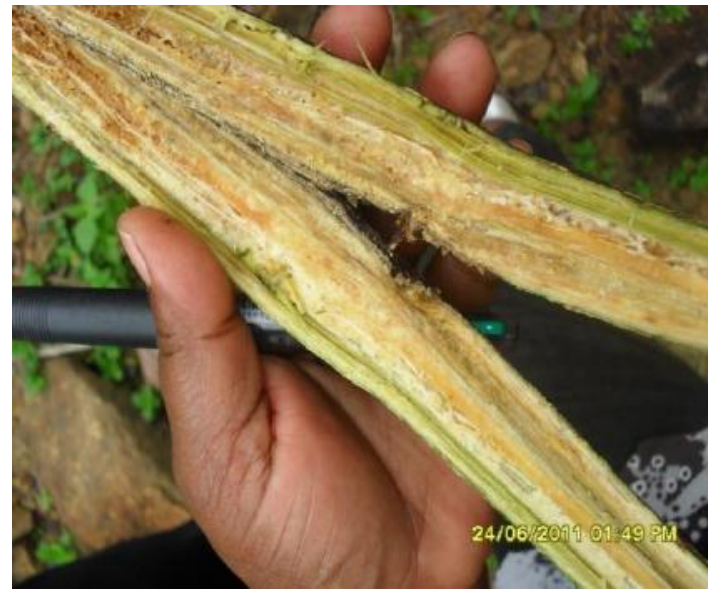

Fig.3: Longitudinal Section of an affected stem

\section{MATERIALS AND METHODS}

A survey was conducted in stembulging reported areas of Ratnapura and Kaluthara districts to find out the causal factors of passion stem bulging. Soil samples were collected from disease infected and disease free locations and analyzed for soil $\mathrm{pH}$, major nutrients and some micro nutrients.

The field trail - 1 was conducted to observe the disease transmission of stem bulging from infected plants to healthy plants. In here, $100 \%$ infected field was selected for the experiment. 60 healthy plants were grown adjacent to the diseased plants and 60 healthy plants were grown in disease free field. Disease incidence level was recorded at two months after planting.

Microscopic observations were made in bulged tissues to detect fungal infection. Affected tissues were microscopically inspected and it was observed fungal mycelium and two types of morphologically different conidia. Pieces of bulged tissues were kept on Potato Dextrose Agar (PDA) medium and incubated 7 days under room temperature. The mycelia development and conidia development on PDA was observed. Then single spore inoculants of fungi isolates were made. Ten isolates were collected and each isolate also wound inoculated into healthy passion fruit vines but and observed for development of bulging symptoms on inoculated stems to confirm Koch's postulates. Also, Passion stem bulging samples were taken and dispatched to the CABI for further diagnosis of causal organism.

The field trail - 2 was conducted at Ratnapura District (Agro ecological zone WL1a) to develop control measures for stem bulging. The experiment was laid out in a Randomize Complete Block Design and five treatments were used with 3 replicates. The treatments were as follows.

\begin{tabular}{|c|l|}
\hline Treatment & \multicolumn{1}{|c|}{ Description } \\
\hline T1 & $\begin{array}{l}\text { Foliar spraying of insecticide - } \\
\text { Thiamethoxam25 WG at the rate of 3g/10 1, two } \\
\text { months after planting and spraying was } \\
\text { continued 3 times in 2 weeks intervals }\end{array}$ \\
\hline T2 & $\begin{array}{l}\text { Foliar spraying of fungicide - Thiophanate } \\
\text { methyl 70 WP at the rate of 6g/ 10 1, two } \\
\text { months after planting and spraying was } \\
\text { continued 3 times in 2 weeks intervals }\end{array}$ \\
\hline T3 & $\begin{array}{l}\text { Alternative foliar spraying of Thiamethoxam 25 } \\
\text { WG and Thiophanate methyl 70 WP, two } \\
\text { months after planting and spraying was } \\
\text { continued 3 times in 2 weeks intervals }\end{array}$ \\
\hline T4 & $\begin{array}{l}\text { Alternative foliar spraying of Thiamethoxam, } \\
\text { Thiophanate methyl and Albert solution (liquid } \\
\text { fertilizer) 5g/10 1, two months after planting and } \\
\text { spraying was continued 3 times in 2 weeks } \\
\text { intervals }\end{array}$ \\
\hline T5 & Control \\
\hline
\end{tabular}




\section{RESULTS AND DISCUSSION}

3.1 Analysis of soil samples collected from passion stem bulging infected fields

Table 1: Analysis of soil samples collected from passion stem bulging infected fields

\begin{tabular}{|c|c|}
\hline Factor & Results \\
\hline $\mathrm{pH}$ & N-5 Acidic \\
\hline $\mathrm{N}, \mathrm{P}$ & Normal \\
\hline $\mathrm{K}$ & Hery high $)$ \\
\hline $\begin{array}{c}\text { Electrical } \\
\text { conductivity }\end{array}$ \\
\hline $\begin{array}{c}\text { Micronutrients } \\
\text { (Fe, Cu, Mn, } \\
\mathrm{Zn})\end{array}$ & Normal \\
\hline
\end{tabular}

Note: Soil samples collected from 10 locations of healthy and disease infected passion fruit cultivation were used for analysis.

Results revealed that soils of those areas were acidic and $\mathrm{P}^{\mathrm{H}}$ of soil samples was varied $4-5$. $\mathrm{K}$ level is higher than normal level. $\mathrm{N}$ and $\mathrm{P}$ levels are within normal range and no $\mathrm{Fe}, \mathrm{Cu}, \mathrm{Mn}, \mathrm{Zn}$ deficiencies observed in the tested soil samples.

\subsection{Transmission of stem bulging from infected plants}

to healthy plants

Table 2: Passion Stem bulging incidence ofnewly planted passion fruit plants which were planted in adjacent to the diseased field and new field

\begin{tabular}{|l|c|}
\hline \multicolumn{1}{|c|}{ Treatment } & \multicolumn{1}{|c|}{$\begin{array}{c}\text { Percent disease } \\
\text { incidence after 2 } \\
\text { months of field } \\
\text { planting }\end{array}$} \\
\hline $\begin{array}{l}\text { T1- Healthy plants growing } \\
\text { adjacent to the diseased } \\
\text { plants }\end{array}$ & 33.3 \\
\hline $\begin{array}{l}\text { T-2 Healthy plants growing } \\
\text { in new land }\end{array}$ & 1.7 \\
\hline
\end{tabular}

Stem bulging symptoms were first observed in T1 treatments within 5 weeks after field planting and later symptoms progressively developed and $33 \%$ plants showed stem bulging symptoms. However, only one plant showed mild symptoms on stem of $\mathrm{T} 2$ treatment during the period. Results numerated that, stem bulging can be transmitted from infected plant to healthy plants.

\subsection{Microscopic observations and characters of} isolation of Fusarium collected from bulged stem

\section{samples of passion fruit.}

Colony colour on PDA was white, and then turns into brown when older. Reverse colony colour on PDA was light brown and then turns into brown when older. There were two types of conidia. Macro conidia were abundant, strait and pointed at ends 3-6 cells. Larger micro conidia were few, cylindrical, 1-2 cells and comparatively smaller. Isolates of fungi were identified as Fusarium spp by comparison of their colony characters and morphological features of conidia with published data [1]. Further, it was noticed that re-inoculation of purified Fusarium isolates failed to development of bulging symptoms of passion fruit vines. However, it was identified by culturing test that Fusarium fungi remained viable in tissues of inoculated sites of vines, indicating that the Fusarium fungi survives in stem tissues of the passion fruit vines without showing bulging symptoms.

\subsection{The field trial based on fungicide and insecticide}

Table 3: Passion Stem bulging incidence five months after field planting

\begin{tabular}{|c|c|}
\hline Treatments & $\begin{array}{c}\text { Mean Passion Stem Bulging } \\
\text { incidence per vine at 5 months } \\
\text { after planting }\end{array}$ \\
\hline T1 & 11.1 \\
\hline T2 & 4.2 \\
\hline T3 & 13.2 \\
\hline T4 & 9.5 \\
\hline T5 & 13.7 \\
\hline
\end{tabular}

Lowest disease incidence was observed in Thiophanate methyl 6g/ 101 i.e. T-2 treated plots of field trials indicating Fusarium species may be the causal factor of the problem. Thiophanate methyl is an approved EU fungicide used widely to control fungal diseases on crops. A systemic fungicide is effective with protective and curative activity against a broad spectrum of diseases in fruits, vegetables and other crops [2]. However, Thiophanate methyl is highly effective on Fusarium sp. [3]. Foliar spraying of insecticide application, alternative foliar spraying of insecticide and fungicide and alternative foliar spraying of insecticide, fungicide and Albert solution were failed in controlling stem bulging in the field conditions. However, according to the CABI report No: IMI 504215 \& IMI 504216, the isolation made from internal tis sues and two fungal cultures were subjected for molecular identification and Gibberella fujikuroi and Fusarium sp. were identified as associate fungi of stem bulging of passion fruit[4].

The fungus, Gibberella fujikuroi produces plant growth hormones called gibberellins. Some strains of the fungus Gibberella fujikuroi (perfect stage of Fusarium moniliforme) are the industrial source of gibberellic acid [5]. These strains infect rice and cause the disease known as bakanae in Japan. Bakanae disease of rice is caused through infection by this fungus and in rice this causes an exaggerated growth response and the plants to become 
extremely tall with a pale spindly appearance [6]. Other hosts are also infected by this fungus although we are unable to find any references concerning passion fruit. The fungus was only isolated from within the bulging areas and therefore we suspect the fungus colonization of the tissues is a localized infection.

\section{CONCLUSION}

The isolation made from internal tissues of passion fruit and two fungal cultures were subjected for molecular identification and Gibberella fujikuroi and Fusarium sp. were identified as associated fungi of stem bulging of passion fruits. Also, these results are compatible with field trails' data. However, Thiophanate methyl 70 WG $6 \mathrm{~g} / 101 \mathrm{can}$ be recommended as an effective fungicide to minimize passion fruit stembulging.

\section{ACKNOWLEDGEMENT}

Grateful acknowledgements are made to Sri Lanka Council for Agriculture Research Policy for the financial assistance provided for this study.

\section{REFERENCES}

[1] Booth C. 1971. The Genus Fusarium, Commonwealth Mycological Institute, Kew, Surrey, England.

[2] IUPAC - International Union of Pure and Applied Chemistry, 2018, thiophanate-methyl (Ref: NF 44)

[3] Anon.2015. Pest Management Recommendations, Department of Agriculture, Sri Lanka.

[4] CABI- Centre for Agriculture and Bioscience International. 2014. Report inquiry No: 37-14.

[5] Jefferys E.G.1970. The gibberellin fermentation. Adv Appl Microboil 13:283-315.

[6] Phinney B.O.1983. The history of gibberellins. In A Crozier, ed, The Biochemistry and Physiology of Gibberellins,Vol1.Prae-ger, NewYork, pp 19-52. 